\title{
HALREV
}

Hasanuddin Law Review

\section{Korelasi Putusan Hakim Tingkat Pertama, Tingkat Banding, dan Tingkat Kasasi (Suatu Studi Tentang Aliran Pemikiran Hukum)}

\author{
The Correlation of Judge Decisions in Courts of First Instance, Appeal, and \\ Final Appeal (A Study on the History of Legal Thought)
}

Mustafa Bola $^{1}$, Romi Librayanto ${ }^{2}$, Muhammad Ilham Arisaputra ${ }^{3^{*}}$

${ }^{1}$ Bagian Dasar-Dasar Ilmu Hukum, Fakultas Hukum, Universitas Hasanuddin Jln. Perintis Kemerdekaan Km. 10, Tamalanrea, Makassar, Sulawesi Selatan, 90245, Indonesia.

${ }^{2}$ Bagian Hukum Administrasi Negara, Fakultas Hukum, Universitas Hasanuddin Jln. Perintis Kemerdekaan Km. 10, Tamalanrea, Makassar, Sulawesi Selatan, 90245, Indonesia .

${ }^{3}$ Bagian Hukum Keperdatan, Fakultas Hukum, Universitas Hasanuddin Jln. Perintis Kemerdekaan Km. 10, Tamalanrea, Makassar, Sulawesi Selatan, 90245, Indonesia .

*Tel./Fax: +62-411-585035 E-mail: ilhamarisaputra@gmail.com

Submitted: Dec 7, 2014; Reviewed: Feb 21, 2015; Accepted: Mar 9, 2015

\begin{abstract}
In order to make a decision, Judge has obliged under the law to conduct the article as a consideration in making any decision. The developing of Legal paradigm has shown an expectation to the court, specially the judges for not only able to give procedural justice based on the law text, but more to the substantive justice. Subtantive Justice is not mean that judge may ignore the law that less of justice, but still put as guideline for the legal formal which have given the justice also the rule of law. Some of the factor that influenced to the implementation on legal paradigm for judge in making any decision is the background of education of the judge, spirit of the corp, external controlling and also the integrity of the Judges decision.
\end{abstract}

Keywords: Judge Decision; Legal Paradigm; Legal idealism

\begin{abstract}
Abstrak: Hakim dalam mengambil putusan dibebankan kewajiban oleh undang-undang untuk memuat pasal tertentu dari peraturan perundang-undangan yang bersangkutan sebagai dasar untuk mengadili. Paradigma hukum yang berkembang menunjukkan adanya harapan agar pengadilan, khususnya hakim, tidak hanya mampu memberikan keadilan prosedural semata berdasarkan teks perundang-undangan, akan tetapi lebih utama adalah keadilan substantif. Keadilan substantif bukan berarti hakim harus selalu mengabaikan bunyi undang-undang, melainkan dengan keadilan substantif berarti hakim bisa mengabaikan undang-undang yang tidak memberi rasa keadilan, tetapi tetap berpedoman pada formal undang-undang yang sudah memberi rasa keadilan sekaligus menjamin kepastian hukum. Faktor-faktor yang berpengaruh terhadap penerapan paradigma hukum bagi hakim dalam memutus perkara adalah faktor pendidikan hakim, lingkungan peradilan (spirit of the corp), pengawasan eksternal, dan integritas hakim.
\end{abstract}

Kata Kunci: Putusan Hakim; Paradigma Hukum; Idealisme Hukum 


\section{PENDAHULUAN}

Sejak dahulu, khasanah ilmu hukum telah diwarnai oleh kontestasi pemikiran hukum. Salah satu aliran yang sangat berpengaruh dalam perkembangan sistem hukum Indonesia adalah aliran positivisme atau analytical positivism atau rechtsdogmatiek. Aliran yang mulai berkembang sejak abad kesembilan belas tersebut merupakan antinomi dari konsep naturalisme yang hidup sebelumnya. Pemikiran hukum naturalis yang menempatkan rasionalitas hukum positif manusia harus bersumber pada akal budi yang diturunkan dari Hukum Alam. ${ }^{1}$

Konsep hukum modern menempatkan positivisme sebagai mainstream yang harus berhadapan dengan suatu problem masyarakat yang kompleks dan rumit. Artinya, positivisme yang hanya mampu memilah dan menyelesaikan persoalan secara hitam putih atas dasar peraturan perundangundangan, harus berhadapan dengan masalah kehidupan manusia yang sangat kompleks dan tidak secara tepat terakomodasi dalam deretan aturan terkodifikasi. Terutama akibat pandangan positivisme yang menempatkan hukum sepenuhnya dipisahkan dari keadilan dan anasir-anasir di luar hukum. Positivisme meyakini bahwa hukum adalah closed logical system, artinya, peraturan dapat dideduksikan dari undang-undang yang dikodifikasi terbebas dari anasir sosiologis, politik, ekonomi, bahkan etika, dan moral, sehingga menjadikan hukum sebagai bidang yang terisolasi dari interaksinya dengan masyarakat.

1 E. Sumaryono. (2002). Etika dan Hukum: Relevansi Teori Hukum Kodrat Thomas Aquinas. Yogyakarta: Kanisius, hlm. 79.
Gelombang kritik terhadap positivisme hukum berangkat dari premis bahwa suatu sistem tidak mungkin sepenuhnya bersifat tertutup. Sistem yang tertutup sama sekali akan menyulitkan penyesuaian kaidahkaidah yang terjadi akibat adanya perubahan dalam masyarakat. Suatu sistem dinyatakan tidak akan lama bertahan hidup jika tidak mendapat dukungan sosial yang luas. Dengan demikian sistem haruslah bersifat terbuka, karena sistem tidak dapat dilepaskan dari sistem sosial lainnya. Memisahkan hukum dengan moral seperti rasa keadilan yang dianut positivisme tidak dapat dianut lagi oleh karena rasa keadilan tersebut merupakan cerminan jiwa kehidupan masyarakat dan aspek penegakan yang termuat dalam kodifikasi tidak akan berarti tanpa adanya dukungan moralitas. ${ }^{2}$

Pranata hukum yang berkiblat pada filsafat positivisme dinilai tidak berdaya untuk menyelesaikan masalah-masalah sosial akibat bangunan sistem hukum beserta doktrin-doktrin yang menopangnya memang tidak memungkinkan hukum melakukan perubahan sosial atau menghadirkan keadilan substantif. Kondisi ini makin diperparah oleh faktor tercemarnya institusiinstitusi hukum karena bekerja sebagai alat kekuasaan dengan watak dogmatika hukum (legal dogmatics) yang menjauhkan diri dari sentuhan aspek-aspek sosial.

Kontestasi pemikiran hukum legal positivism dengan cara pandangnya yang bersifat abstrak dan formal legalistis, melahirkan beberapa pemikiran hukum dengan

2 Lihat Rikardo Simarmata, Socio Legal Studies dan Gerakan Pembaharuan Hukum. Available at: http://www.huma.or.id/document/ [Diakses 6 September 2014]. 
konsep paradigma yuridis sosiologis atau yuridis empiris, diantaranya aliran sejarah hukum. Dalil utama aliran pemikiran hukum ini adalah hukum timbul tidak semata karena perintah penguasa atau kekuasaan, tetapi karena perasaan keadilan yang terletak di dalam jiwa bangsa (volkgeist). ${ }^{3}$

Antitesis terhadap aliran sejarah dan utamanya positivisme adalah pemikiran hukum sociological jurisprudence yang berpendapat bahwa hukum yang baik haruslah hukum yang sesuai dengan hukum yang hidup dalam masyarakat. Teori ini memisahkan secara tegas antara hukum positif dengan hukum yang hidup. Dalil utama tentang hukum, tidak lagi merupakan persoalan tentang legalitas formal, mengenai penafsiran pasal-pasal peraturan perundangundangan secara semestinya, melainkan bergerak ke arah penggunaan hukum sebagai sarana untuk turut membentuk tata kehidupan yang baru tersebut atau sesuai dengan kondisi saat itu. ${ }^{4}$ Di sisi lain, berkembang juga aliran Realisme Hukum, yang inti gagasannya bahwa hukum adalah alat untuk mencapai tujuan-tujuan sosial dan tidak memercayai adanya suatu anggapan bahwa peraturan-peraturan dan konsepkonsep hukum itu sudah mencukupi untuk menunjukkan apa yang harus dilakukan oleh pengadilan. $^{5}$

3 L. B. Curzon. (1995). Jurisprudence: Lecture Notes Series, $2^{\text {nd }}$ ed. London: Cavendish Publishing. Ltd., hlm. 130.

4 Lihat lebih lanjut elaborasi sociological jurisprudence dalam Suri Ratnapala. (2009). Jurisprudence. New York: Cambridge University Press, hlm. 188-189.

$5 \quad$ L.B. Curzon, Op.Cit., hlm. 169-175. Lihat pula dalam Ian McLeod. (2003). Legal Theory. $2^{\text {nd }}$ Ed. New York: Palgrave Macmillan, hlm. 137149.
Beranjak dari terdapatnya kontestasi dalam pemikiran hukum dalam khasanah ilmu hukum, merupakan suatu hal yang penting untuk melihat apakah kontestasi tersebut juga memengaruhi atau merebak dalam kehidupan nyata pelaksanaan hukum. Terutama dalam koridor putusan pengadilan sebagai benteng terakhir pencari keadilan, yang saat ini masih terdapat tudingan bahwa harapan terhadap lembaga peradilan belum sepenuhnya dapat memuaskan seluruh pihak. Tudingan kepada pranata peradilan secara otomatis dialamatkan kepada hakim sebagai penguasa utama dalam proses pengadilan.

Profesi hakim sebagai salah satu bentuk profesi hukum sering digambarkan sebagai pemberi keadilan. Oleh karena itu, hakim juga digolongkan sebagai profesi luhur (officium nobile), yaitu profesi yang pada hakikatnya merupakan pelayanan pada manusia dan masyarakat. ${ }^{6}$ Hakim sebagai figur sentral dalam proses peradilan senantiasa dituntut untuk mengasah kepekaan nurani, memelihara kecerdasan moral dan meningkatkan profesionalisme dalam menegakkan hukum dan keadilan bagi masyarakat. Terutama dalam posisinya yang senantiasa harus memberi putusan dengan pernyataan "Demi Keadilan Berdasarkan Ketuhanan Yang Maha Esa".

Salah satu tudingan yang dialamatkan kepada profesi hakim adalah seringnya terdapat putusan-putusan yang tidak sesuai

$6 \quad$ Apapun kondisi yang dipersepsikan terhadap profesi hukum di Indonesia dewasa ini, profesi hukum secara intrinsik tetap merupakan pofesi luhur yang dibutuhkan oleh masyarakat, bangsa, dan negara. Lihat dalam Sidharta. (2006). Moralitas Profesi Hukum: Suatu Tawaran Kerangka Berpikir. Bandung: PT. Refika Aditama, hlm. 4. 
dengan rasa keadilan masyarakat (substantive justice) yang disebabkan masih digunakannya paradigma positivisme dalam menangani suatu perkara. Masih banyak ditemukan hakim yang dalam pengambilan keputusannya hanya menganut pola pikir positivistik yang sangat didominasi oleh perspektif legalisme, formalisme, dan dogmatisme, karena semua putusan harus diambil bertumpu pada bunyi peraturan semata.

Namun, dapat ditemukan pembelaan hakim yang memandang asas legalitas di atas segalanya. Prinsip legalitas yang diabstraksi dari pemaknaan Hans Kelsen ${ }^{7}$ tentang "keadilan berdasarkan hukum". Bahwa keadilan dalam pengertian yang bermakna legalitas adalah suatu peraturan umum yang benar-benar diterapkan kepada semua kasus yang menurut isi peraturan tersebut harus diterapkan. Peraturan itu tidak adil jika diterapkan pada suatu kasus tetapi tidak diterapkan pada kasus lain yang serupa. Sehingga keadilan adalah suatu kualitas yang berhubungan bukan dengan isi dari suatu tatanan hukum positif (law in book), melainkan pada penerapannya (law in action). Perbuatan seseorang dinyatakan adil atau tidak adil dalam arti berdasarkan hukum, adalah perbuatan tersebut sesuai atau tidak sesuai dengan suatu norma hukum yang dianggap absah oleh subjek yang menilainya.

Kontestasi pemikiran hukum tentu akan sangat berpengaruh pada pola pikir atau paradigma hakim dalam menelaah dan mengambil keputusan atas suatu kasus.

7 Hans Kelsen. The Pure Theory of Law. Penerjemah: Raisul Muttaqin. (2009). Teori Hukum Murni. Bandung: Nusa Media, hlm. 17-18.
Seberapa jauh kontestasi ini memengaruhi serta bagaimana para hakim menggunakan konsep-konsep pemikiran hukum yang ada, merupakan serangkaian masalah yang perlu dikaji dalam kenyataannya.

\section{METODE}

Penelitian ini merupakan penelitian yang bersifat yuridis normatif atau penelitian doktrinal $^{8}$, yakni pendekatan masalah yang mempunyai maksud dan tujuan untuk mengkaji perundang-undangan dan peraturan yang berlaku juga kajian teoritis dari literatur yang ada yang kemudian dihubungkan dengan permasalahan yang menjadi pokok pembahasan yang dibahas di dalam penelitian ini. Penelitian ini menganalisis korelasi putusan hakim tingkat pertama, tingkat banding, dan tingkat kasasi dalam hubungannya dengan aliran-aliran pemikiran hukum yang berkembang.

Adapun bahan hukum yang digunakan dalam penelitian ini adalah sebagai berikut: 1) Bahan Hukum Primer, yaitu bahan hukum yang bersifat mengikat yang terdiri atas Undang-Undang Nomor 48 Tahun 2009 tentang Kekuasaan Kehakiman dan putusan pengadilan; 2) Bahan Hukum Sekunder, yaitu

8 Lihat lebih lanjut: Zudan Arif Fakrulloh. (2011). Ilmu Lembaga dan Pranata Hukum (Sebuah Pencarian), Edisi 2. Jakarta: Rajawali Pers, hlm. 35. Penelitian hukum "normatif" disebut pula sebagai "penelitian hukum doktrinal", sedangkan penelitian hukum "sosiologis" acapkali disebut sebagai disebut pula sebagai "penelitian hukum nondoktrinal." Lihat: Soetandyo Wignjosoebroto, "Ragam-ragam Penelitian Hukum" dalam Sulistyowati Irianto dan Sidharta (ed). (2011). Metode Penelitian Hukum: Konstelasi dan Refleksi. Jakarta: Yayasan Pustaka Obor, hlm. 121 et seq. Lihat juga: Mike McConville dan Wing Hong Chui (eds). (2007). Research Methods for Law. Edinburgh University Press, hlm. 3-6. 
bahan hukum yang memberikan penjelasan mengenai bahan hukum primer yang terdiri atas literatur-literatur dan makalah-makalah, karya-karya ilmiah, serta artikel-artikel yang berkaitan dengan objek penelitian; dan 3) Bahan Hukum Tersier, yaitu bahan hukum yang memberi petunjuk maupun penjelasan terhadap bahan hukum primer dan sekunder yang terdiri atas Kamus Hukum dan Kamus Bahasa Indonesia.

Penelitian lapangan dilakukan untuk memperoleh keterangan mengenai segala sesuatu yang berkaitan dengan paradigma hukum hakim dalam memutus perkara. Penelitian ini dilaksanakan di lingkup lembaga peradilan umum dalam wilayah Negara Republik Indonesia. Secara spesifik, penelitian dilaksanakan di Pengadilan Tinggi Sulawesi Selatan dan Sulawesi Barat. Adapun yang akan menjadi narasumber dalam penulisan ini adalah Hakim Pengadilan Tinggi.

Bahan-bahan hukum yang telah dikumpulkan dan diinventarisasi kemudian diolah dan dikaji secara mendalam sehingga diperoleh gambaran yang utuh mengenai persoalan hukum yang diteliti. Bahan hukum primer, sekunder maupun tersier yang telah disinkronisasi secara sistematis kemudian dikaji lebih lanjut berdasarkan teori-teori hukum yang ada sehingga diperoleh rumusan ilmiah untuk menjawab persoalan hukum yang dibahas dalam penelitian hukum ini. ${ }^{9}$ Pengolahan dan analisis bahan hukum bertujuan untuk menemukan kebenaran

9 Bernard Arief Sidharta. Penelitian Hukum Normatif: Analisis Penelitian Filosofikal dan Dogmatikal, sebagaimana dikutip dalam Sulistyowati Irianto dan Sidharta. (2011). Metode Penelitian Hukum: Konstelasi dan Refleksi. Cetakan Kedua. Jakarta: Yayasan Pustaka Obor, hlm. 145. pragmatis dan/atau koherensi. ${ }^{10}$ Pengolahan dan analisis bahan hukum tersebut sangat substansial dalam penelitian hukum dikarenakan bahan-bahan hukum tersebut bersifat preskriptif.

\section{ANALISIS DAN PEMBAHASAN Idealisme Hukum}

Legal idealism dalam hal ini diterjemahkan sebagai idealisme hukum, mencakup teoriteori yang mencari dan berusaha merumuskan cita-cita (ideal) serta nilai-nilai yang mendasari suatu sistem hukum. Adapun kategori-kategori yang digunakan sangat umum. Meskipun, pendekatan yang disebut legal idealism itu cukup luas, sehingga mungkin orang dapat mengklasifikasikan sebagian besar teori di bawah judul ini sebab hanya sedikit teori yang pada analisis terakhir tidak ditegakkan di atas, atau paling tidak berusaha untuk mencapai atau mengambil, sesuatu cita-cita (ideal) atau nilai-nilai akhir.

Idealisme hukum menggunakan pendekatan Hukum Alam (natural law), yang digagas oleh banyak ahli, sejak dari zaman klasik seperti Aristoteles (384-322 SM) dan Cicero (106-43 SM), St. Thomas Aquinas (1225-74), ${ }^{11}$ hingga ahli yang lahir pada abad ke-20, John Finnis (1929). ${ }^{12}$ Jelas jumlahnya juga akan bergantung kepada definisi atau gambaran seseorang tentang Hukum Alam. tetapi dalam arti yang murni yakni meliputi teori-teori yang menjadikan cita-cita dan

10 Philipus M. Hadjon dan Tatiek Sri Djatmiati. (2005). Argumentasi Hukum. Yogyakarta: Gadjah Mada University Press, hlm. 9.

11 Mark Tebbit. (2005). Philosophy of Law: An introduction, $2^{\text {nd }} E d$. New York: Routledge, hlm. 12.

12 John Finnis. (2011). Natural Law and Natural Rights, $2^{\text {nd }} E d$. Oxford: Oxford University Press, hlm. 23 et seqq. 
nilai sebagai analisisnya, pendekatan ini mempunyai banyak pengikut.

Penggunaan cita-cita dan nilai sebagai analisis merupakan sebab dan sekaligus akibat dari kenyataan bahwa teori Hukum Alam mempunyai pengaruh yang sangat besar, sekali pun berbeda-beda dari waktu ke waktu, paling tidak dalam kurun waktu 2500 tahun terakhir ini. Teori ini terutama mempunyai peranan yang sangat menonjol di dunia barat dan bahkan kadang-kadang dipersamakan dengan cara pemikiran hukum barat itu sendiri.

Dalam definisi yang sempit, pendekatan HukumAlam meliputi sudutpandang berbeda-beda tentang berbagai persoalan. Walaupun demikian terlihat adanya sejumlah kesamaan. Inti dari pendekatan ini dengan jitu telah disimpulkan oleh Chroust sebagai berikut :

Semenjak saat kelahirannya hukum alam terutama merupakan suatu pencarian terhadap arti yang akhir dan mutlak dari hukum dan keadilan. Sebab dalam dirinya sendiri ia mengandung satu unsur dasar, yakni bahwa ia berusaha untuk mencari ide-ide dan nilai-nilai yang komperehensif yang mengatasi fakta dan data-data empiris tertentu saja; bahwa ia tidak pernah henti-hentinya mencari pandangan lebih tinggi yang mempersatukan yang akan memberi hukum suatu pengertian di atas "ketentuan yang naif; dan ia berusaha untuk menemukan pada tingkat yang lebih tinggi satu hukum di antara berbagai hukum. ${ }^{13}$

Dengan kata lain, faktor yang tetap (constant) dalam Hukum Alam adalah suatu appeal terhadap sesuatu yang lebih tinggi ini

13 A. Chroust, On the Nature of the Nature Law, sebagaimana dikutip dalam P. Sayre (Ed). (1947). Intrepretation of Modern Legal Philosophies; Essays in Honor of Roscoe Pound. New York, hlm 70-84. dipandang sebagai suatu petunjuk (directive) atau banyak cita-cita ideal serta nilai (value) telah dikemukakan sebagai faktor akhir yang lebih tinggi.

Hukum Alam secara sederhana dapat dibedakandalamduagolongan. ${ }^{14}$ Disatupihak adalah golongan yang dapat disebut sebagai teokratis atau religius yang pada akhirnya mendasarkan diri pada semacam sumber ilahiah. Di lain pihak mazhab metafisika (metaphysical) dan sekuler (secular) di dalam Hukum Alam mendasarkan diri pada struktur dan atau lingkungan fisik, apapun perbedaan di antara berbagai penganjur Hukum Alam sehubungan dengan "sumber" terakhir dalam teori mereka, dalam hal ini pun mereka menunjukkan satu unsur yang sama.

Pada analisis terakhir, setiap penganjur Hukum Alam dapat dicirikan oleh sifat mistis atau ideologis, sebab tiang utama dari teori mereka pada akhirnya tidak dapat diverifikasi secara ilmiah oleh pihak yang lain. Dari sudut pandang pihak yang tidak percaya (non believer) seluruh teori Hukum Alam dimulai dari praduga dan karenanya merupakan semacam keyakinan (faith).

Melihat sifatnya yang demikian ini, maka tidak mengherankan apabila Hukum

14 W. Friedmann, Legal Theory (Teori dan Filsafat Hukum: Idealisme Filosofis dan Problema Keadilan - Susunan II). hlm 345-346. Memakai empat pembagian untuk menjelaskan landasan apa yang disebutnya "absolute ideal of justice"; 1. Teori yang berpijak pada landasan yang teologis; 2. Deduksi legal atas prinsip-prinsip hukum khusus dari suatu citacita keadilan absolut yang metafisis dan juga rasional; 3. Teori-teori hukum yang mendasarkan pengetahuan tentang keadilan pada inspirasi dan instuisi; dan 4. Usaha-usaha untuk mendeduksi prinsip-prinsip keadilan dan landasan rasional universal. 
Alam telah dipergunakan untuk mem-bela semua dan aneka macam posisi. Ia akan dijadikan sandaran untuk memberikan justifikasi dan juga untuk menyangkal suatu tertib hukum tertentu, dan dalam kontroversi yang lebih khusus setiap pihak telah memakai Hukum Alam untuk memperkuat kedudukannya.

\section{Korelasi Putusan Hakim pada Putusan Pengadilan Tingkat Pertama, Tingkat Banding, dan Tingkat Kasasi dalam Konteks Paradigma Hukum}

Pengadilan sebagai pilar utama dalam penegakan hukum dan sumber keadilan menempatkan hakim sebagai aktor utama atau figur sentral dalam proses peradilan yang senantiasa dituntut untuk mengasah kepekaan nurani, memelihara integritas, kecerdasan moral dan meningkatkan profesionalisme dalam menegakkan hukum dan keadilan bagi rakyat banyak. Lembaga peradilan adalah perpanjangan tangan dari tujuan pembentukan hukum, yaitu sebagai alat untuk menemukan keadilan.

Kelompok realisme hukum yang dipelopori Oliver Wendell Holmes bahkan memandang bahwa hukum adalah apa yang diputuskan oleh peradilan (the prophecies of what the court will do... are what I mean by the law). ${ }^{15}$ Demikian pula Karl Llewellyn yang mengungkapkan bahwa: "what officials do about disputes is the law it self." 16

Dalam sudut pandang aliran Antropologi Hukum yang dipelopori oleh Schapera

15 Mahkamah Konstitusi RI. (2010). Perkembangan Pengujian Perundang-undangan di Mahkamah Konstitusi. Jakarta: Konstitusi Press, hlm. 41

16 Ibid. yang menyatakan "law is any rule of conduct likely to be enforced by the courts" (hukum adalah setiap aturan tingkah laku yang mungkin diselenggarakan oleh pengadilan). ${ }^{17}$

Paradigma hukum yang berkembang menunjukkan adanya harapan agar pengadilan, khususnya hakim, tidak hanya mampu memberikan keadilan prosedural semata berdasar teks perundang-undangan, akan tetapi lebih utama adalah keadilan substantif. Keadilan substantifbukan berarti hakim harus selalu mengabaikan bunyi undang-undang, melainkan dengan keadilan substantif berarti hakim bisa mengabaikan undang-undang yang tidak memberi rasa keadilan, tetapi tetap berpedoman pada formal undangundang yang sudah memberi rasa keadilan sekaligus menjamin kepastian hukum. Ini berarti bahwa apa yang secara formal benar bisa saja disalahkan secara materiil dan substansinya melanggar keadilan. Demikian sebaliknya, apa yang secara formal salah bisa saja dibenarkan jika secara materiil dan substansinya sudah cukup adil.

Dalam konteks ini, Posner ${ }^{18}$ mengemukakan bahwa:

That judicial decisions are determined by "the law," conceived of as a body of preexisting rules found stated in canonical legal materials, such as constitutional and statutory texts and previous decisions of the same or a higher court, or derivable from those materials by logical operations.

Dalam perspektif hukum progresif, keadilan substantif dapat diwujudkan jika seorang hakim mampu berhukum dengan melakukan lompatan lebih dari sekedar

17 Ibid., hlm. 42

18 Richard A. Posner. (2008). How Judges Think. Cambridge: Harvard University Press, hlm. 19 
tugas dan kewenangan yang diberikan oleh teks aturan formal. ${ }^{19}$ Upaya pemenuhan rasa keadilan itu bergantung kepada bagaimana cara seorang hakim dalam memutuskan perkara. Jika Hakim gagal mengurai makna keadilan substantif dalam setiap perkara, makayang ditemukan adalah keadilan absurd. Bagi hakim, atau pihak yang diuntungkan, mungkin suatu putusan adalah adil tapi putusan tersebut tak mampu memenuhi keadilan dalam konteks memulihkan relasitas kemanusiaan yang sebelumnya terganggu kembali dalam taraf harmoni antara satu dengan lainnya. Pengadilan bukanlah sekadar tempat untuk menentukan pemenang dan pecundang, tetapi pengadilan melalui putusan hakim adalah sarana untuk re-harmonisasi kehidupan manusia.

Proses hakim dalam menelusuri ruang dalam suatu perkara atau yang disebut konsep aktivitas hukum (judicial activism) ${ }^{20}$, memberikan ruang dan kesempatan bagi seorang hakim untuk menggunakan pengetahuan personalnya sehingga menuntunnya memutuskan sebuah permasalahan. Pengetahuan personal yang dimaksud dalam proses penyelesaian perkara hukum tentunya dalam konteks ilmu hukum. Dalam hal ini paradigma hukum yang dianut oleh hakim akan sangat berpengaruh, di samping pengetahuan hukum lainnya. Responden penelitian, Zainuddin, seorang Hakim Pengadilan

\footnotetext{
19 Ibid. hlm. 45

20 Menurut Black Law Dictionary (Bryan Garner; 2004, hlm. 850), judicial activism dapat dimaknai sebagai sebuah filosofi dari pembuatan putusan peradilan dimana hakim diperbolehkan menggunakan pengetahuan personalnya mengenai kebijakan publik, di antara pelbagai faktor-faktor, untuk menuntunnya memutuskan sebuah permasalahan.
}

Tinggi Makassar, mengungkapkan bahwa pada praktiknya, proses pengambilan dan pembuatan putusan oleh hakim di pengadilan, baik dalam perkara perdata maupun pidana merupakan proses yang kompleks dan sulit dilakukan sehingga memerlukan pendidikan, pelatihan, pengalaman dan kebijaksanaan. Pertimbangan hakim sangat ditentukan oleh pengetahuan hukum hakim yang bersangkutan.

Tugas yustisial seorang hakim adalah memeriksa, mengadili, dan menjatuhkan putusan atas suatu perkara hukum. Soedikno Mertokusumo menguraikan bahwa dalam rangka melakukan penemuan hukum, umumnya dilakukan metode interpretasi dan konstruksi hukum. ${ }^{21}$ Metode interpretasi hukum dilakukan terhadap aturan yang sudah ada, namun mengandung norma yang kabur (vage normen), konflik antar norma hukum (antinomy normen) dan ketidakpastian suatu peraturan perundangundangan jika berhadapan dengan peristiwa hukum. Sedangkan metode konstruksi hukum dilakukan apabila ditemukan adanya kekosongan hukum (recht vacuum) atau kekosongan undang-undang (wet vacuum).

Pendekatan yang digunakan hakim pada konteks ini tetap mengacu pada pendekatan filsufis, normatif, dan empiris ${ }^{22}$. Konteks pendekatan ini sama dengan

21 Soedikno Mertokusumo. (2001). Penemuan Hukum, Sebuah Pengantar. Yogyakarta: Liberty, hlm. 52.

22 Pendekatan Filsufis untuk pendekatan nilai termasuk nilai moralitas, pendekatan normatif untuk pendekatan yurisprudensi (ilmu hukum normatif), dan pendekatan empiris untuk pendekatan sosiologis. Achmad Ali. (2002). Menguak Tabir Hukum: Suatu Kajian Filosofis dan Sosiologis. Cet. Kedua. Jakarta: PT. Gunung Agung, hlm. 176 
pendekatan yang ada sebelumnya, yakni:

a. Pendekatan moralitas, yang focal concern-nya landasan moral hukum, dan validitas hukumnya adalah konsistensi hukum dengan etikaeksternal atau nilai-nilai moral.

b. Pendekatan yurisprudensi (ilmu hukum normatif), yang focal concernnya independensi hukum, dan validitas hukumnya adalah konsistensi internal hukum dengan aturan-aturan, normanorma, dan asas-asas yang dimiliki hukum sendiri.

c. Pendekatan sosiologis, yang focal concern-nya hukum dan tindakan sosial, dimana validitas hukumnya adalah konsekuensi-konsekuensi hukum bagi masyarakatnya.

Dalam memutus suatu perkara, pendekatan ketiganya, yakni filsufis, normatif, dan empiris adalah model pendekatan yang digunakan oleh hakim. Pendekatan normatif memfokuskan kajiannya dengan memandang hukum sebagai suatu sistem yang utuh yang mencakup perangkat asasasas hukum, norma-norma hukum, dan aturan-aturan hukum baik yang tertulis maupun tidak tertulis. Asas hukum yang melahirkan norma hukum dan norma hukum yang melahirkan kaidah atau aturan hukum. Dari satu asas hukum dapat lahir lebih dari satu norma hukum dan dari satu norma hukum melahirkan lebih dari satu kaidan atau aturan hukum. Jadi melalui pendekatan normatif ini, hakim menggunakan peraturan perundang-undangan sebagai senjata utama dalam memutus suatu perkara.

Selanjutnya pendekatan empiris, dimana pendekatan ini memfokuskan kaji- annya dengan memandang hukum sebagai perangkat realitas, tindakan, dan perilaku. Jadi hakim dalam memutus perkara tidak hanya menggunakan peraturan perundangundangan sebagai pijakan utamanya, tetapi juga melihat dan mengkaji secara nalar realitas yang ada terhadap perkara yang dihadapinya. Pendekatan yang terakhir adalah pendekatan filsufis, dimana pendekatan ini memfokuskan kajiannya dengan memandang hukum sebagai seperangkat nilai-nilai moral dimana nilai moral ini yang kemudian mengantarkan kepada keadilan.

Dari ketiga pendekatan yang dipaparkan di atas, pendekatan yang mendominasi para hakim dalam menerapkan hukum dan memutus perkara adalah pendekatan normatif dan pendekatan empiris. Pendekatan normatif melihat hukum dalam wujud aturan, norma atau asas, hakim menilai suatu perkara yang ditanganinya berdasarkan peraturan perundang-undangan sehingga pada posisi inilah kemudian hakim dinilai memiliki paradigma positivistis dalam membuat suatu keputusan. Pendekatan empiris tidak melihat hukum hanya semata-mata berwujud aturan, norma, atau asas, tetapi melihat hukum sebagai seperangkat realitas, seperangkat tindakan, dan seperangkat perilaku yang mencakupi sosiologis, antropologis, psikologis, ekonomis, dan religius. Pendekatan filsufis hanya digunakan sebagai penunjang oleh hakim dalam memutus perkara sehingga tidak tercermin secara menyeluruh rasa keadilan bagi para pihak yang berperkara.

Penggunaan ketiga pendekatan tersebut di atas disebut Menski sebagai triangular concept of legal pluralism. ${ }^{23}$ Penggunaan

\footnotetext{
$23 \quad$ Ibid, hlm. 185
} 
pendekatan ini sering digunakan pada negara-negara yang memiliki pluralisme hukum, seperti di Amerika. Di Indonesia sendiri setiap daerah memiliki hukum lokal masingmasing dimana perilaku hukum dari masingmasing individu atau kelompok di setiap daerah yang ada berbeda-beda dan tentu saja sangat tidak realistis ketika berbagai sistem hukum, sistem peradilan, dan hukum positif yang beranekaragam tersebut hanya dikaji dengan menggunakan satu atau dua metode pendekatan hukum. Pluralisme atau keberanekaragaman hukum lokal inilah yang juga turut memengaruhi hakim dalam memutus suatu perkara sehingga hakim dituntut untuk menggunakan ketiga metode pendekatan tersebut untuk menelaah dan menganalisis suatu perkara sampai kemudian memberikan keputusan yang adil bagi para pihak.

Putusan yang akan ditetapkan oleh suatu persidangan perkara hukum diambil berdasarkan hasil musyawarah majelis hakim, yang bersifat rahasia. Dalam sidang permusyawaratan, setiap hakim wajib menyampaikan pertimbangan atau pendapat tertulis terhadap perkara yang sedang diperiksa dan menjadi bagian yang tidak terpisahkan dari putusan. Dalam praktiknya, hakim termuda golongan dan pangkatnya dipersilakan untuk terlebih dahulu untuk menyampaikan pertimbangan hukumnya, setelah itu selanjutnya hakim yang lebih senior dan diakhiri oleh Hakim Ketua Majelis. Jika terdapat perbedaan pendapat, maka diambil berdasarkan suara terbanyak, dan pendapat yang berbeda tersebut dapat dimuat dalam putusan sebagai dissenting opinion dan Hakim yang berbeda pendapat tersebut tetap wajib menandatangani putusan.
Ketidaksepakatan umumnya muncul berdasarkan alasan atau berkorelasi dengan ideologi, atau karena latar belakang pribadi atau pengalaman, emosional, atau faktor lain kemungkinan untuk membangkitkan sebuah ketidaksepakatan yang sulit untuk diselesaikan dengan argumen beralasan. Dalam konteks ini, pengetahuan dan paradigma hukum berperan penting.

Dalam rapat permusyawaratan majelis hakim, maka yang selalu menjadi pertimbangan adalah bahan referensi yang menjadi rujukan dari masing-masing anggota majelis. Jadi kembali kepada pengetahuan hukum dari hakim yang bersangkutan dan apabila masing-masing anggota majelis merasa argumentasi yang menjadi dasar pertimbangannya cukup kuat, maka pada akhirnya pengambilan putusan dilakukan voting. Hakim sebagai figur sentral dalam penegakan hukum, maka hakim memiliki kewajiban moral dan tanggung jawab profesional untuk mengusai pengetahuan dan keterampilan teknis. Dengan adanya kecukupan pengetahuan dan keterampilan, maka hakim dalam memutus suatu perkara akan dapat memberikan pertimbangan hukum (legal reasoning) yang tepat dan benar.

Menjadi persoalan berikutnya adalah adanya kewajiban aturan tentang tata cara permusyawaratan majelis hakim bahwa setiap putusan pengadilan selain harus memuat alasan dan dasar putusan, juga memuat pasal tertentu dari peraturan perundang-undangan yang bersangkutan. Sebagaimana aturan mengharuskan bahwa setiap pertimbangan hukum harus mencantumkan pasal-pasal pokok yang berkaitan dengan substansi pertimbangan. Secara umum, ditemukan bahwa 
cara hakim memaknai sebuah aturan hukum umumnya menggunakan dua pola tafsir, yaitu original intent atau non-original intent, biasa disebut juga dengan tekstual meaning atau contextual meaning, yang sesungguhnya perwujudan dari pola kontestasi antara penganut paham positivisme hukum dan sosiologi hukum.

Walaupun hukum yang berkuasa sebagaimana diuraikan di atas, tetapi bukan berarti bahwa hukum itu diciptakan tanpa memperhatikan anasir-anasir di luar hukum, utamanya moralitas. Hukum adalah perlindungan kepentingan manusia, hukum adalah untuk manusia, sehingga rule of law tidak boleh diartikan bahwa manusia pasif dan menjadi budak hukum. Hukum dibentuk dengan dasar moral mampu memprediksikan gejala sosial yang akan ditimbulkan. Gejala sosial ini kemudian berimplikasi lagi terhadap hukum itu sendiri sehingga hukum itu dikatakan pula merupakan produk yang mutakhir yang mampu mengikuti perkembangan zaman. Dengan demikian pula, maka dapat dipahami bahwa kebenaran yang ada dalam hukum merupakan kebenaran yang sifatnya relatif.

Hakim dalam pengambilan keputusan terhadap perkara yang sedang dihadapi, tidak sekedar sebagai terompet undang-undang saja. Hakim seyogyanya mendasarkan putusannya sesuai dengan memerhatikan kesadaran hukum dan perasaan hukum serta kenyataan-kenyataan yang sedang hidup di dalam masyarakat, ketika putusan itu dijatuhkan. Upaya mencari hukum yang tepat dalam menyelesaikan perkara yang dihadapkan kepadanya, hakim yang bersangkutan dapat melakukan penemuan hukum.
Faktor-faktor yang Berpengaruh Terhadap Penerapan Paradigma Hukum bagi Hakim dalam Memutus Perkara

Sebagai figur sentral dalam penegakan hukum, paradigma hakim akan sangat dipengaruhi oleh sistem hukum yang berlaku. Sistem hukum Indonesia yang bersifat pluralisme merupakan kombinasi berbagai sistem hukum dengan dominasi utama bersumber dari sistem hukum Eropa Kontinental (the civil law system) akibat warisan kolonialisme. Jika begitu banyak pandangan dan literatur yang menyatakan bahwa hukum di Indonesia lebih bersifat positivisme, maka faktor yang dituding sebagai penyebab utama adalah akibat pengaruh sistem hukum Eropa Kontinental (the civil law system). Karakter utama the civil law system adalah adanya kodifikasi, undang-undang menjadi sumber hukum yang utama dan sistem peradilan yang bersifat inkuisitorial yang artinya bahwa hakim berhak untuk mendapatkan bukti dalam kasus yang disidangkannya.

Berdasarkan ketiga karakteristik tersebut, maka jelaslah bahwa paradigma hukum hakim lebih kepada mengedepankan undang-undang sebagai sumber hukum yang utama sehingga penulis menilai pula bahwa hakim di Indonesia dominan berparadigma positivisme.

Dalam sistem civil law, hukum adalah identik dengan undang-undang, sedangkan kebiasaan dan ilmu pengetahuan hukum diakui sebagai hukum apabila undangundang menunjuknya. Akibat sejarahnya, sistem ini mengkodifikasi undang-undang untuk membatasi hakim yang karena kebebasannya telah menjurus ke arah kesewenang-wenangan atau tirani. 
Dominasi sistem hukum warisan kolonialisme disebut menjadi faktor utama mengapa paradigma hukum dan penegakan hukum di Indonesia sangat bersifat positifistik, termasuk paradigma hakim, walaupun terdapat sistem hukum lain yang disinyalir sebagai volkgeist bangsa Indonesia. Misalnya, sistem hukum adat dan hukum Islam. Pengadopsian sistem hukum kolonialis belum tentu sesuai dengan tradisi berhukum negeri jajahan, sebagaimana yang diutarakan Robert B. Seidman dalam gagasannya tentang "the law of the non-transferable law". Menurutnya, hukum undang-undang yang berasal dari suatu negeri yang dibentuk berdasarkan kondisi sosial-kultural tertentu tidaklah akan bisa diterapkan begitu saja pada suatu kelompok penduduk dengan kesadaran sosial-kultural yang berbeda.

Kecaman Cornelis van Vollenhoven, anggota Raad van State di pemerintahan Gubernur Jenderal di Batavia pada tahun 1840an, juga senada dengan kritiknya yang menyatakan:

Bagaimana mungkin di suatu negeri yang dihuni jutaan penduduk yang memiliki tradisinya sendiri, lebih-lebih penduduk Muslim yang taat sekali kepada hukum tulisnya sendiri, dapat diterapi hukum yang dimaksudkan hanya untuk mengatur kehidupan orang Eropa. Boleh dikhawatirkan bahwa kebijakan seperti ini akan menggoyahkan sendi-sendi kehidupan orang pribumi. ${ }^{24}$

Walaupun secara umum didominasi oleh sistem hukum Eropa Kontinental, eksistensi sistem hukum Islam dan hukum

24 Dalam tulisan Soetandyo Wignjosoebroto, Hukum Yang Tak Kunjung Tegak: Apa Yang Salah Dengan Kerja Penegakan Hukum Di Negeri Ini?, Dimuat dalam Komisi Yudisial Republik Indonesia, Dialektika Pembaruan Sistem Hukum Indonesia, Juli 2012 adat masih tetap dipertahankan, sehingga menimbulkan pluralisme hukum. Namun dalam praktik penegakan hukum, sistem hukum yang berlaku lebih mengandalkan pada bentuk-bentuk hukum tertulis, Para pelaksana dan penegak hukum senantiasa mengarahkan pikiran hukum pada peraturanperaturan tertulis. Kaidah hukum adat atau hukum Islam hanya dipergunakan dalam hal-hal yang secara hukum ditentukan harus diperiksa dan diputus menurut kedua hukum tersebut. Demikian pula untuk penggunaan yurisprudensi dalam mempertimbangkan suatu putusan, itu hanya sekedar untuk mendukung peraturan hukum tertulis yang menjadi sumber utamanya.

Hakim dalam memeriksa dan memutus perkara, menghadapi suatu kenyataan bahwa hukum tertulis tersebut ternyata tidak selalu menyelesaikan masalah yang dihadapi. Bahkan seringkali hakim sering menemukan sendiri hukum itu (rechtsvinding) dan atau menciptakan hukum (rechtscheping) untuk melengkapi hukum yang sudah ada dalam memutus suatu perkara. Hakim atas dasar inisiatif sendiri harus menemukan hukum, karena hakim tidak boleh menolak perkara dengan alasan hukum tidak ada, tidak lengkap, atau hukumnya samar-samar. Gangguan terhadap penegakan hukum mungkin terjadi apabila ada ketidakserasian antara nilai, kaidah dan pola prilaku. Gangguan tersebut terjadi apabila terjadi ketidakserasian antara nilai-nilai yang menjelma di dalam kaidahkaidah dan pola prilaku yang tidak terarah yang mengganggu kedamaian pergaulan hidup.

Para hakim dipengaruhi oleh berbagai faktor kognitif dalam menjatuhkan putusan- 
nya. Paling besar pengaruhnya bagi hakim dalam memutuskan suatu perkara adalah, opini publik. Para hakim akan sangat memperhatikan pendapat masyarakat terhadap kasus yang ditanganinya. Dalam putusan, mereka cenderung tidak melawan arus dengan menjatuhkan putusan sebangun dengan opini masyarakat tersebut, karena ini berkaitan dengan keselamatan sang hakim sendiri. Kemudian menurutnya, pengaruh kedua disebut sebagai attitudinal model atau perspektif sikap. Kemudian ada yang disebut social background model, yaitu lingkungan sosialnya mempengaruhi putusan. Misalnya, dalam kasus perebutan hak asuh. Hakim yang berusia tua, cenderung memberikan hak asuh ke ibu. Mereka terpengaruh, pengalaman karena tidak pernah familiar dengan peran ayah sebagai pengasuh. Tapi jika hakim dari generasi baby boomer mereka bisa menerima ayah juga bisa berperan sebagai pengasuh.

Untuk kasus di Indonesia, menurut Reza Indragiri Amriel, hakim cenderung memberikan vonis ringan pada kasus korupsi, ini ada kaitannya dengan spirit of the corp, yaitu saat akan menjatuhkan vonis, para hakim akan melihat vonis-vonis terdahulu. Sehingga mereka menjatuhkan vonis pada rentang yang tidak terlalu jauh dari vonis sejenis lain. ${ }^{25}$

Hakim dalam mengaktualisasi ide keadilan memerlukan situasi yang kondusif, baik yang berasal dari faktor eksternal maupun internal dari dalam diri seorang Hakim. Jika ditelusuri, faktor-faktor yang mempengaruhi Hakim dalam mentransformasikan ide keadilan, setidaknya dapat dipetakan

\footnotetext{
25 Ibid.
}

sebagai berikut: 1) Jaminan terhadap kebebasan peradilan/Hakim; 2) Kualitas profesionalisme Hakim; dan 3) Penghayatan etika profesi Hakim. Faktor pertama merupakan faktor eksternal, sedangkan dua faktor terakhir merupakan faktor internal.

Kebebasan peradilan (indepedency of judiciary) sudah menjadi keharusan bagi tegaknya negara hukum (rechstaat). Hakim akan mandiri dan tidak memihak dalam memutus sengketa, dan dalam situasi yang kondusif tersebut, Hakim akan leluasa untuk mentransformasikan ide-ide dalam pertimbangan-pertimbangan putusan. Di Indonesia jaminan terhadap telah dipertegas dalam penjelasan Pasal 3 Ayat (1) Undang-Undang No. 48 Tahun 2009 tentang Kekuasaan Kehakiman yang mengatur bahwa "dalam menjalankan tugas dan fungsinya, hakim dan hakim konstitusi wajib menjaga kemandirian peradilan". Dalam bagian Penjelasan Undang-Undang Kekuasaan Kehakiman tersebut dijelaskan bahwa yang dimaksud dengan "kemandirian peradilan" adalah bebas dari campur tangan pihak luar dan bebas dari segala bentuk tekanan, baik fisik maupun psikis.

Faktor kualitas profesionalitas hakim, dijelaskan Catur Iriantoro, bahwa melaksanakan tugas secara profesional artinya memiliki kemampuan dan ketrampilan Hakim untuk melaksanakan efesiensi dan efektifitas putusan. Baik dari segi penerapan hukumnya, maupun kemampuan mempertimbangkan putusan berdasarkan nilai-nilai keadilan yang tumbuh dan berkembang dalam masyarakat, serta kemampuan memprediksi reaksi dan dampak sosial atas putusan yang telah dijatuhkannya. Menurutnya, dalam 
upaya mewujudkan profesionalisme Hakim, maka seyogyanya para Hakim memiliki penguasaan ilmu yang mendalam dan wawasan yang luas, yang tercermin dalam bobot dan untuk putusan yang dijatuhkan dengan kemampuan untuk mengetahui, memahami dan menghayati hukum yang berlaku serta mempunyai keberanian menjatuhkan keputusan berdasarkan hukum dan keadilan.

Sementara faktor penghayatan etika profesi hakim dimaknai sebagai asasasas moralita yang mendasari profesi Hakim, sebagai pegangan dalam bersikap dan bertindak selama mengemban dan menjalankan jabatan Hakim, baik di dalam maupun di luar kedinasan. Ikatan Hakim Indonesia (IKAHI) telah merumuskan kode kehormatan Hakim Indonesia dalam bentuk Panca Dharma Hakim, yang merupakan suatu bentuk pengawasan terhadap anggotanya. Panca Dharma Hakim ini merupakan nilainilai yang bersifat abstrak, yang terdiri dari Kartika (bertaqwa kepada Tuhan Yang Maha Esa), Cakra (berlaku adil), Candra (bijaksana), Tirta (jujur) dan Sari (berbudi luhur).

Faktor selanjutnya yang juga diekstraksi dari teori-teori yang ada, adalah faktor masyarakat itu sendiri yakni lingkungan dimana hukum tersebut berlaku atau diterapkan. Hakim sebagai aparatur penegakan hukum berasal dari masyarakat, melaksanakan tugasnya yang bertujuan untuk mencapai kedamaian dalam masyarakat. Oleh karena itu, dipandang dari sudut tertentu, maka masyarakat dapat mempengaruhi paradigma hukum hakim. Kebenaran hukum yang ada dalam masyarakat harus diperhatikan oleh hakim dalam membuat suatu keputusan karena apa yang kemudian diputuskan oleh hakim memiliki dampak yang sangat besar bagi masyarakat.

Budaya hukum masyarakat juga memiliki andil dalam konteks ini. Menurut teori Lawrence Meir Friedman, budaya hukum (culture law) adalah suasana pemikiran sosial dan kekuatan sosial yang menentukan bagaimana hukum digunakan, dihindari, atau disalahgunakan. Budaya hukum erat kaitannya dengan kesadaran hukum masyarakat. Semakin tinggi kesadaran hukum masyarakat maka akan tercipta budaya hukum yang baik dan dapat merubah pola pikir masyarakat mengenai hukum selama ini. Secara sederhana, tingkat kepatuhan masyarakat terhadap hukum merupakan salah satu indikator berfungsinya hukum.

Namun perlu diingat bahwa sesungguhnya lembaga peradilan adalah tempat untuk menyelesaikan persoalan-persoalan hukum agar tidak berkembang menjadi konflik yang membahayakan keamanan dan ketertiban masyarakat. Menurut Satjipto Rahardjo, fungsi itu hanya akan efektif apabila pengadilan memiliki 4 (empat) prasyarat: ${ }^{26}$

1. Kepercayaan (masyarakat) bahwa di tempat itu mereka akan memperoleh keadilan seperti mereka kehendaki;

2. Kepercayaan (masyarakat) bahwa pengadilan merupakan lembaga yang mengekspresikan nilai-nilai kejujuran, mentalitas yang tidak korup dan nilai-nilai utama lainnya;

3. Waktu dan biaya yang mereka keluarkan tidak sia-sia;

4. Pengadilan merupakan tempat bagi orang untuk benar-benar memperoleh perlindungan hukum.

26 Satjipto Rahardjo. (1986). Hukum dan Perubahan Sosial. Bandung: Alumni, hlm. 107. 
Selain faktor sistem hukum yang berlaku dan faktor-faktor yang diuraikan berdasarkan beragam teori tersebut, maka bersumber dari hasil penelitian empirik yang dilakukan, ditemukan pengakuan bahwa faktor-faktor yang juga berpengaruh dalam hal paradigma hukum hakim adalah faktor pendidikan, pengalaman kerja, pengawasan eksternal, integritas, ekonomi dan gender. Seluruh responden penelitian ini secara homogen mengemukakan bahwa faktor paling utama dalam persoalan paradigma hukum bagi seorang hakim adalah pendidikan.

Faktor berikutnya yang dinilai turut berpengaruh dalam membentuk paradigma hukum bagi seorang hakim adalah pengalaman kerja. Masa kerja atau lamanya menggeluti profesi hakim serta jumlah kasus yang ditangani adalah unsur-unsur yang mempengaruhi pengalaman kerja seorang hakim. Responden penelitian ini mengatakan bahwa pengalaman kerja turut memberikan pe ngaruh terhadap keberanian hakim di dalam mengambil keputusan, termasuk cara pandang atau paradigma hakim terhadap telaah hukum atas kasus yang dihadapinya. Sebagaimana telah diurakan pada bagian terdahulu, bahwa pengalaman kerja juga berpengaruh pada proses rapat permusyawaratan hakim dalam pengambilan keputusan. Seringkali hakim yang masih muda golongan dan pangkatnya tidak mampu berbuat banyak bilamana berbeda pendapat dengan hakim yang lebih senior apalagi ketua majelis hakim.

Menurut Binsar Gultom, hakim yang mampu menyusun dan membuat pertimbangan hukum dari rangkaian keterangan saksi, terdakwa dan alat-alat bukti yang terungkap dipersidangan adalah merupakan pengalaman dari sosok hakim yang sudah digeluti bertahun-tahun lamanya, bukan dilakukan oleh hakim yang baru. ${ }^{27}$ Menurutnya, hal tersebut terkecuali bagi hakim adhoc yang memang memiliki spesialisasi keilmuan dan pengalaman mumpuni dibidang teori akademis akan menjadi kombinasi yang sempurna dengan pengalaman hakim karier dalam merumuskan suatu putusan, sehingga terhindar celah kekurangan suatu putusan.

Dalam teori hukum keputusan yang salah yang menghapuskan kekuatan legal dari produk perundang-undangan legislatif tidak dapat dipertanggung-jawabkan secara hukum dikarenakan tidak terdapat hak dan kewajiban sebagai konsekuensi dari kesalahan tersebut. Kesalahan tersebut menurut Hart memperlihatkan sisi lain yang menyangkal bahwa pengadilan dipayungi adagium "A supreme tribunal has the last word in saying what the law is" atau "hukum adalah apa yang pengadilan putuskan'. Hart menjelaskan pandangannya itu sebagai berikut: ${ }^{28}$

A supreme tribunal has the last word in saying what the law is and, when it has said it, the statement that the court was 'wrong' has no consequences within the system: no one's rights or duties are thereby altered. The decision may, of course, be deprived of legal effect by legislation, but the very fact that resort to this necessary demonstrates the empty character, so far as the is concerned, of the statement that the court's decision was wrong. Consideration of these facts makes

27 Binsar Gultom. Pro-Kontra Putusan Bebas Pengadilan. Dimuat pada Harian Analisa Senin, 14 Nov 2011.

28 H.L.A. Hart. (1994). The Concept of Law. Oxford University Press, New York, hlm. 141 
it seem pedantic to distinguish, in the case of a supreme tribunal's decisions, between their finality and infallibility. This leads to another form of denial that courts in deciding are ever bound by rules: "The law (or the constitution) is what the courts say it is.

Pertimbangan hukum yang tidak benar dapat terjadi karena berbagai kemungkinan Hakim tidak mempunyai cukup pengetahuan hukum tentang masalah yang sedang ditangani, Hakim sengaja menggunakan dalil hukum yang tidak benar atau tidak semestinya karena adanya faktor lain seperti adanya tekanan pihak-pihak tertentu, suap, dan faktor-faktor lain yang mempengaruhi indepensi Hakim yang bersangkutan, Hakim tidak memiliki cukup waktu untuk menuliskan semua argumen hukum yang baik disebabkan karena terlalu banyaknya perkara yang harus diselesaikan dalam kurun waktu yang relatif singkat. Atau mungkin akibat Hakim malas untuk meningkatkan pengetahuan dan wawasannya, sehingga berpengaruh terhadap kualitas putusan yang dibuatnya. Faktor ini merupakan faktor yang pengaruhnya tidak langsung, namun cukup menentukan kualitas putusan.

Menurut Richard A. Posner, ${ }^{29}$ tidak ada kriteria seragam untuk pemilihan hakim, hakim-hakim pengadilan yang sama cenderung beragam di latar belakang dan kemampuan, yang merupakan sumber ketegangan serta berbagai memperkaya pengalaman dan wawasan. Mempertahankan kolegialitas dalam kondisi seperti itu membutuhkan terus menerus upaya untuk meminimalkan sumber iritasi-seperti sepaham. Posner mengatakan:

\footnotetext{
29 Richard A. Posner. Op.Cit., hlm 33.
}

There are no uniform criteria for the selection of judges, the judges of the same court tend to be diverse in background and ability, which is a source of tension as well as of an enriching variety of experiences and insights. Maintaining collegiality under such conditions requires continuous efforts at minimizing sources of irritation - such as dissents.

Jika dibandingkan dengan pendidikan calon hakim di negeri Belanda, maka menurut buku panduan pendidikan calon hakim Belanda, agar seorang hakim atau jaksa dinilai memiliki pengalaman yang cukup untuk keahlian dasar membutuhkan waktu minimal tujuh tahun. Dalam berbagai penelitian disebutkan juga pengalaman lebih dari 10.000 jam, yaitu pengalaman, latihan, dan refleksi yang intensif pada tugas yang telah ditentukan. Ini berarti bahwa setelah hakim menyelesaikan studinya, proses menjadi profesional terus berlangsung. Hal ini berpengaruh pada aspek kognitif hakim atau kepercayaan seseorang tentang sesuatu yang didapatkan dari proses berpikir tentang seseorang atau sesuatu. Proses yang dilakukan disini adalah memperoleh pengetahuan dan memanipulasi pengetahuan melalui aktivitas mengingat, menganalisis, memahami, menilai, menalar, membayangkan dan berbahasa.

Pekerjaan hakim senantiasa berhubungan dengan hajat hidup manusia. Harapan pencari keadilan hanya tertuju pada penegak hukum utamanya kepada hakim. Apabila putusan hakim tidak cukup mempertimbangkan tentang hal-hal yang memiliki keterkaitan secara yuridis dan sah sebagaimana yang diungkap oleh para pihak di persidangan, atau yang ditemukan oleh hakim selama dalam proses pemeriksaan suatu perkara, 
maka akan terasa adanya kejanggalan dan mematikan rasa keadilan para pencari keadilan. Di sinilah faktor kognitif hakim sangat memegang peranan penting karena hakim dituntut mampu memahami hukum secara komperehensif.

Hakim dalam memutus suatu perkara tidak hanya melihat membaca hukum yang tertulis akan tetapi yang utama dan terpenting adalah memperhatikan nilainilai yang hidup dan memenuhi rasa keadilan masyarakat yang bersangkutan atau lingkungan sosial. Lingkungan sosial di sini diartikan sebagai lingkungan peradilan dimana hakim cenderung memberikan vonis yang ada kaitannya dengan spirit of the corp, yaitu saat akan menjatuhkan vonis, para hakim akan melihat vonis-vonis terdahulu sehingga mereka menjatuhkan vonis pada rentang yang tidak terlalu jauh dari vonis sejenis lain.

Pada konteks Ini, hakim menjatuhkan vonis tidak selalu melakukan verifikasi terhadap fakta hukum, konstruksi hukum, dan penerapan hukum yang tepat, tetapi juga menjaga identitas korps agar solid. Tetapi faktor ini tidak begitu mempengaruhi pemikiran hakim dalam memutus perkara, hakim lebih menitikberatkan independensinya dibandingkan spirit of the corp. Indepedensi yang dimiliki hakim memiliki keterkaitan dengan gagasan kekuasaan kehakiman yang merdeka, dalam hal ini adalah indepedensi yudisial.

Faktor berikutnya yang mempengaruhi paradigma hukum hakim dalam penyelesaian perkara, berdasarkan hasil penelitian empirik, adalah pengawasan eksternal. Dalam konteks ini, pengawasan eksternal dapat dilakukan oleh institusi resmi, dalam hal ini Komisi Yudisial, kemudian pengawasan dapat dilakukan melalui organisasi kemasyarakatan, serta media massa atau pers. Adanya pengawasan eksternal sesungguhnya memberikan pengaruh psikologis bagi hakim dalam mengambil keputusan.

Kekhawatiran akan dampak atau reaksi atas putusan yang dilakukan juga turut menyumbang terbentuknya perilaku hakim yang hanya mengutamakan paradigma positifistik. Dengan berlindung bahwa putusan-putusan yang diambil telah sesuai dengan norma peraturan perundang-undangan serta prosedural standar, maka hakim seolah menyatakan bahwa mereka telah melakukan apa yang semestinya sesuai dengan sistem hukum yang berlaku. Keadilan hukum terpenuhi karena adanya kepastian hukum. Menurut pengakuan salah seorang hakim dalam penelitian ini bahwa pengawasan langsung dari Komisi Yudisial, termasuk menyumbang kekhawatiran hakim terhadap melakukan putusan yang progresif atau melakukan terobosan.

Tugas Komisi Yudisial dalam Menjaga dan Menegakkan kehormatan, keluhuran martabat, serta perilaku hakim, diatur dalam Pasal 20 ayat (1) Undang-Undang Nomor 18 Tahun 2011, yaitu:

a. Melakukan pemantauan dan pengawasan terhadap perilaku Hakim;

b. Menerima laporan dari masyarakat berkaitan dengan pelanggaran Kode Etik dan/ atau Pedoman Perilaku Hakim.

c. Melakukan verifikasi, klarifikasi, dan investigasi terhadap laporan dugaan pelanggaran Kode Etik dan/atau Pedoman Perilaku Hakim secara tertutup;

d. Memutuskan benar tidaknya laporan dugaan pelanggaran Kode Etik dan/atau Pedoman Perilaku Hakim; 
e. Mengambil langkah hukum dan/atau langkah lain terhadap orang perseorangan, kelompok orang, atau badan hukum yang merendahkan kehormatan dan keluhuran martabat Hakim.

Faktor terakhir yang diindikasi turut berpengaruh terhadap paradigma hukum seorang hakim adalah persoalan integritas (ethos) yang bermakna kejujuran dan dapat dipercaya. Berdasarkan Pedoman Perilaku Hakim, integritas tinggi pada hakekatnya bermakna mempunyai kepribadian utuh tak tergoyahkan, yang terwujud pada sikap setia dan tangguh berpegang pada nilainilai atau norma-norma yang berlaku dalam melaksanakan tugas. Integritas tinggi akan mendorong terbentuknya pribadi yang berani menolak godaan dan segala bentuk intervensi, dengan mengedepankan tuntutan hati nurani untuk menegakkan kebenaran dan keadilan, dan selalu berusaha melakukan tugas dengan segala cara-cara terbaik untuk mencapai tujuan terbaik.

Persoalan integritas, khususnya jika berkaitan dengan ekonomi, sepertinya tidak memiliki keterkaitan langsung dengan persoalan paradigma hukum seorang hakim, karena persoalan ekonomi tidak berkorelasi dengan aspek kognitif pengetahuan. Akan tetapi dalam berbagai kasus yang telah terjadi, demikian pula hasil penelitian menunjukkan bahwa perilaku hakim yang tidak jujur atau tidak memiliki integritas yang baik, dalam penerapan hukum pada pertimbangan suatu kasus seringkali berupaya untuk mencari celah hukum yang menguntungkan seseorang atau pihak yang memiliki hubungan tertentu dengannya. Modusnya antara lain penjatuhan vonis bebas (vrijspraak) dan putusan "lepas dari segala tuntutan hukum" (onstlag van allerechtsvervolging) ataupun vonis yang lebih ringan dari hukuman maksimal.

Pada saat hakim memberikan putusan bebas atau sanksi lebih ringan dari hukuman maksimal terhadap kasus-kasus yang menyita perhatian publik, seperti kasus korupsi, maka seringkali putusan tersebut dinilai tidak mencerminkan rasa keadilan masyarakat. Tudingan bahwa hakim terjebak atau masih berparadigma positivistik tidak dapat dihindarkan. Namun tidak berarti bahwa dengan demikian maka hakim berada dalam posisi yang harus disalahkan, terutama jika hakim telah memiliki keyakinan bahwa keputusan yang diambilnya telah melalui mekanisme yang seharusnya. Misalnya, secara prosedural hukum formil, menerapkan aturan yang tepat, telah memperhatikan berbagai prinsip hukum, telah menggali nilai-nilai yang hidup dalam masyarakat serta mempertimbangkan aspek moralitas, maka jika seluruhnya telah membentuk "keyakinan hakim" maka apapun putusan tersebut sesugguhnya telah sesuai dengan yang seharusnya.

Selain daripada itu, persoalan ekonomi ternyata juga dipengaruhi oleh persoalan gender. Sepertinya pernyataan ini cukup mengejutkan, akan tetapi menjadi sangat logis dalam penjelasan Ketua Pengadilan Negeri Makassar Andi Isna Resniswari yang diperoleh dalam penelitian ini. Menurutnya, bagi seorang hakim wanita yang bersuami akan cenderung lebih idealis dan mudah melakukan terobosan hukum karena tidak terbebani oleh faktor tekanan atas dasar ekonomi karena hidupnya ditopang oleh suami. Berbeda dengan hakim laki-laki beristri yang sangat bergantung pada profesi 
hakim sebagai sumber penghasilan satusatunya, sehingga bilamana terjadi hal-hal yang tidak diinginkan berkaitan dengan putusan yang diambil dapat mempengaruhi karier sehingga cenderung formalistik dan dogmatis.

Pernyataan tersebut menunjukkan signifikansi relasi antara faktor integritas, faktor ekonomi dan paradigma hakim teradap hukum. Hal ini seolah membenarkan anekdot di antara para akuntan yang menyebutkan, "If money starts talking, even the angel starts listening”.

\section{PENUTUP}

Dalam penerapan peraturan perundangundangan, seorang hakim dalam mengambil keputusan dibebankan kewajiban oleh Undang-Undang Nomor 48 Tahun 2009 tentang Kekuasaan Kehakiman (Pasal 50 ayat 1) untuk harus memuat pasal tertentu dari peraturan perundang-undangan yang bersangkutan yang dijadikan dasar untuk mengadili. Dominasi pandangan hukum tertentu dalam pertimbangan hukum adalah bahwa paradigma hukum yang berkembang menunjukkan adanya harapan agar pengadilan, khususnya hakim, tidak hanya mampu memberikan keadilan prosedural semata berdasar teks perundang-undangan, akan tetapi lebih utama adalah keadilan substantif. Keadilan substantif bukan berarti hakim harus selalu mengabaikan bunyi undang-undang, melainkan dengan keadilan substantif berarti hakim bisa mengabaikan undang-undang yang tidak memberi rasa keadilan, tetapi tetap berpedoman pada formal undang-undang yang sudah memberi rasa keadilan sekaligus menjamin kepastian hukum.

Faktor-faktor yang berpengaruh terhadap penerapan paradigma hukum bagi hakim dalam memutus perkara dapat diuraikan sebagai berikut: Pertama, pendidikan hakim. Pendidikan formal hakim, baik strata 1 sampai dengan strata 3 sangat penting karena dalam rapat permusyawaratan sangat ditentukan oleh banyaknya referensi yang menjadi bahan pertimbangan dalam menilai suatu fakta hukum yang dihadirkan oleh para pihak dalam persidangan; Kedua, lingkungan Peradilan. Faktor ini bisa dilihat dalam beberapa bentuk, misalnya opini publik dan spirit of the corp; Ketiga, pengawasan eksternal. Dalam konteks ini, pengawasan eksternal dilakukan oleh institusi resmi, dalam hal ini Komisi Yudisial. Selain itu, pengawasan juga dapat dilakukan melalui organisasi kemasyarakatan serta media massa atau pers; Keempat, integritas. Hakim atas dasar inisiatif sendiri harus menemukan hukum. Paradigma hukum seorang hakim tidak bisa dilepaskan dari persoalan integritas (ethos) yang bermakna kejujuran dan dapat dipercaya.

Pemikiran hukum perlu dikembangkan ke arah paradigma komplementif, yaitu paradigma bahwa dalam mempersoalkan hukum, baik dalam tataran teoretis maupun penegakan hukum oleh hakim tidak diperlukan adanya pertentangan antara satu aliran dengan aliran lainnya sehingga hukum dipandang secara holistik dan digunakan sebagai saling melengkapi. Dengan menggunakan paradigma yang bersifat komplementer, maka sesungguhnya hakim telah melaksanakan idea dari sistem hukum yang mengatur tentang kekuasaan kehakiman. 
Sehingga diperlukan upaya untuk melakukan pelatihan bagi hakim untuk menyusun pertimbangan hukum dan putusannya yang didasari oleh keterpaduan paradigma hukum yang ada.

\section{BIBLIOGRAFI}

Achmad Ali. (2002). Menguak Tabir Hukum: Suatu Kajian Filosofis dan Sosiologis. Cetakan kedua. Jakarta: PT. Gunung Agung.

Binsar Gultom. Pro-Kontra Putusan Bebas Pengadilan. Harian Analisa. Edisi Senin, 14 November 2011.

Bryan Garner. (2004). Black Law Dictionary. Oxford University Press, 2nd edition.

E. Sumaryono. (2002). Etika dan Hukum: Relevansi Teori Hukum Kodrat Thomas Aquinas, Yogyakarta: Kanisius.

H.L.A. Hart. (1994). The Concept of Law. New York: Oxford University Press.

Hans Kelsen. The Pure Theory of Law. Penerjemah: Raisul Muttaqin. (2009). Teori Hukum Murni. Bandung: Nusa Media.

Ian McLeod. (2003). Legal Theory. $2^{\text {nd }} E d$. New York: Palgrave Macmillan.

John Finnis. (2011). Natural Law and Natural Rights, $2^{\text {nd }}$ Ed. Oxford: Oxford University Press.

L. B. Curzon. (1995). Jurisprudence: Lecture Notes Series, $2^{\text {nd }}$ Ed. London: Cavendish Publishing. Ltd.

Mahkamah Konstitusi RI. (2010). Perkembangan Pengujian Perundang-undangan di Mahkamah Konstitusi. Jakarta: Konstitusi Press.

Mark Tebbit. (2005). Philosophy of Law: An introduction, $2^{\text {nd }} E d$. New York: Routledge.
Mike McConville dan Wing Hong Chui (Ed). (2007). Research Methods for Law Edinburgh University Press.

P. Sayre. (Ed). (1947). Intrepretation of Modern Legal Philosophies; Essays in Honor of Roscoe Pound. New York

Philipus M. Hadjon dan Tatiek Sri Djatmiati. (2005). Argumentasi Hukum, Cetakan kedua. Yogyakarta: Gadjah Mada University Press.

Richard A. Posner. (2008). How Judges Think. Cambridge: Harvard University Press.

Rikardo Simarmata. Socio Legal Studies dan Gerakan Pembaharuan Hukum. Available from: http://www.huma.or.id/document/ [Diakses pada tanggal 6 September 2014].

Satjipto Rahardjo. (1986). Hukum dan Perubahan Sosial. Bandung: Alumni.

Sidharta. (2006). Moralitas Profesi Hukum: Suatu Tawaran Kerangka Berpikir, Bandung: PT. Refika Aditama.

Soedikno Mertokusumo. (2001). Penemuan Hukum, Sebuah Pengantar, Yogyakarta: Penerbit Liberty.

Soetandyo Wignjosoebroto. (2012). Hukum Yang Tak Kunjung Tegak: Apa Yang Salah Dengan Kerja Penegakan Hukum Di Negeri Ini?. Dialektika Pembaruan Sistem Hukum Indonesia, Edisi Juli 2012.

Sulistyowati Irianto dan Sidharta (Ed). (2011). Metode Penelitian Hukum: Konstelasi dan Refleksi, Cet. Kedua Jakarta: Yayasan Pustaka Obor.

Suri Ratnapala. (2009). Jurisprudence. New York: Cambridge University Press.

Zudan Arif Fakrulloh. (2011). Ilmu Lembaga dan Pranata Hukum (Sebuah Pencarian), Edisi 2. Jakarta: Rajawali Pers. 